\title{
НЕПРЕРЫВНЫЙ СИНТЕЗ ВТОРИЧНЫХ И ТРЕТИЧНЫХ АМИНОВ ГИДРИРОВАНИЕМ И ВОССТАНОВИТЕЛЬНЫМ АМИНИРОВАНИЕМ НИТРИЛОВ
}

\author{
А.О. Панов, В.М. Мохов, Е.В. Шепотько, Ю.В. Попов \\ Волгоградский государственный технический университет, \\ 400005, Россия, г. Волгоград, пр. В.И. Ленина, 28.
}

DOI: 10.19163/MedChemRussia2021-2021-244

E-mail: tons@vstu.ru

Одним из способов получения алкиламинов, являющихся ценными полупродуктами в фармакологии, является реакция гидрирования нитрилов. Наиболее широко применяется каталитическое восстановление нитрилов в первичные амины. Однако, применение данного процесса для направленного получения вторичных и третичных аминов является недостаточно разработанным.

Целью настоящей работы являлось разработка способа непрерывного получения аминов гидрированием нитрилов на наночастицах никеля, иммобилизованных на твердом носителе.

В качестве катализатора были использованы наночастицы никеля, нанесенные на цеолит $\mathrm{NaX}$ или $\gamma-\mathrm{Al}_{2} \mathrm{O}_{3}$. Для получения диалкиламинов нами проведено гидрирование нитрилов.

$$
\begin{gathered}
\text { R-CN } \underset{80-200^{\circ} \mathrm{C}}{\stackrel{\mathrm{Ni}^{0}, \mathrm{H}_{2}(1 \mathrm{aTm})}{\longrightarrow}} \quad \mathrm{RCH}_{2} \mathrm{NH}_{2}+\left(\mathrm{RCH}_{2}\right)_{2} \mathrm{NH}+\left(\mathrm{RCH}_{2}\right)_{3} \mathrm{~N} \\
\text { R= Et, Pr, i-Pr, Ph }
\end{gathered}
$$

Основными продуктами реакции являлись симметричные диалкиламины, выход которых достигал 95\%.

Показано, что введение в реакционную смесь вторичных циклических аминов позволяет получить несимметричные третичные алкиламины.

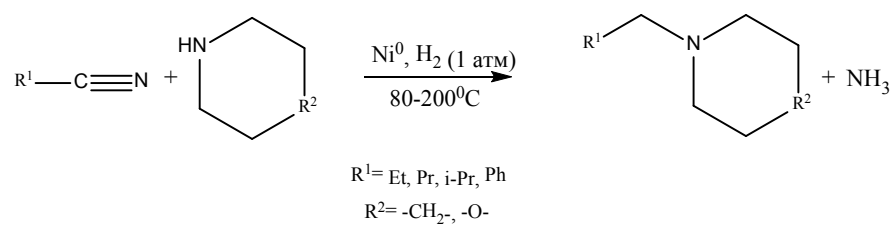

Показано, что в данных условиях выход целевых продуктов достигает 90\%. Способ может быть рекомендован для малотоннажного синтеза алкиламинов в производстве фармакологических средств. 